

\title{
Synthesis and characterization of partially bio-based polyimides based on biphenylene-containing diisocyanate derived from vanillic acid
}

\author{
Sachin Kuhire, Amol Ichake, Etienne Grau, Henri Cramail, Prakash
}

Wadgaonkar

\section{- To cite this version:}

Sachin Kuhire, Amol Ichake, Etienne Grau, Henri Cramail, Prakash Wadgaonkar. Synthesis and characterization of partially bio-based polyimides based on biphenylene-containing diisocyanate derived from vanillic acid. European Polymer Journal, 2018, 109, pp.257-264. 10.1016/j.eurpolymj.2018.09.054 . hal-01972928

\section{HAL Id: hal-01972928 \\ https://hal.science/hal-01972928}

Submitted on 20 Nov 2019

HAL is a multi-disciplinary open access archive for the deposit and dissemination of scientific research documents, whether they are published or not. The documents may come from teaching and research institutions in France or abroad, or from public or private research centers.
L'archive ouverte pluridisciplinaire HAL, est destinée au dépôt et à la diffusion de documents scientifiques de niveau recherche, publiés ou non, émanant des établissements d'enseignement et de recherche français ou étrangers, des laboratoires publics ou privés. 
Synthesis and Characterization of Partially Bio-Based Polyimides Based on Biphenylene-Containing Diisocyanate Derived from Vanillic Acid

\title{
Sachin S. Kuhire ${ }^{a, c}$, Amol B. Ichake ${ }^{a, b, c}$, Etienne Grau ${ }^{b}$, Henri Cramail ${ }^{b *}$, Prakash P. Wadgaonkar,c**
}

${ }^{a}$ Polymer Science and Engineering Division, CSIR-National Chemical Laboratory, Pune 411008, India.

bLaboratoire de Chimie des Polymères Organiques, UMR 5629, CNRS, Université de Bordeaux, Bordeaux INP/ENSCBP, 16 avenue Pey Berland, 33600, Pessac, France. ${ }^{c}$ Academy of Scientific and Innovative Research (AcSIR), Delhi-Mathura Road, New Delhi, 110025 , India.

*Corresponding Authors: E-mail: cramail@enscbp.fr (Henri Cramail), pp.wadgaonkar@ncl.res.in (Prakash P. Wadgaonkar)

Keywords: Renewable resources; Lignin; Vanillic acid; Diisocyanate; Aromatic polyimide; Step-growth polymers

\begin{abstract}
A new bio-based biphenylene-containing diisocyanate, namely, 5,5'-diisocyanato2,2',3,3'-tetramethoxy-1,1'-biphenyl (BDI) was synthesized starting from vanillic acid -a lignin-derived phenolic acid. A series of new partially bio-based polyimides was prepared by polycondensation of BDI with five commercially available aromatic dianhydrides. Polyimides exhibited good solubility in organic solvents and medium molecular weights (Mn $(\mathrm{GPC}$, polystyrene standard $\left.)=25,100-32,200 \mathrm{~g} \mathrm{~mol}^{-1}\right)$. Polyimides showed good thermal stability with $10 \%$ degradation temperature and glass transition temperature in the range $459-473{ }^{\circ} \mathrm{C}$ and $262-329{ }^{\circ} \mathrm{C}$, respectively.
\end{abstract}

\section{Introduction}

Aromatic polyimides represent an important class of high performance polymers due to their excellent thermal, mechanical and chemical resistance properties. Polyimides often replace glass and metals and are mainly used in industrial sectors such as automotive, aerospace, gas separation, electronic packaging, adhesives, etc [1-4]. 
Aromatic polyimides possess rigid chains and strong inter-chain interactions originating from their intra- and inter-chain charge transfer complex (CTC) formation and electronic polarization, which results in their poor solubility in organic solvents, and consequently possess difficulties in their processability [5]. Therefore, significant efforts have been made in the past to improve the solubility and melt processability of aromatic polyimides by structural modifications which include: i) incorporation of hinge atoms, alkylene or 'kinked' structure in polymer backbone [6-8] and, ii) incorporation of pendant bulky substituents or flexible groups [9-11]. The incorporation of 'kinked' units in polyimide backbone is of great interest because it results in solubility enhancement without much compromise on thermal characteristics [12].

The key monomers used for the synthesis of aromatic polyimides are diamines/diisocyanates and dianhydrides. Most of these monomers are derived from petroleum-based chemicals [13-15]. However, the use of petroleum resources for the synthesis of polymers is insecure because of their finite stocks, non-renewability and environmental issues [16-18]. In this context, academic and industrial research laboratories have focused the attention on monomers and polymers based on bio-resources such as starch, cellulose, lignin, cashew nut shell liquid (CNSL), terpenes and so on [11,18-23]. A range of difunctional monomers useful for the preparation of polymers such as (semi)aromatic polycarbonates, polyesters, polyamides and polyimides have been reported [10,11,20,24-26]. On the other hand, only limited examples of bio-based difunctional monomers such as diamines and diisocyanates suitable for synthesis of aromatic polyimides are available in the literature $[6,9,11,27-37]$.

The objective of the present work was to synthesize biphenylene-containing diisocyanate, namely, 5,5'-diisocyanato-2,2',3,3'-tetramethoxy-1,1'-biphenyl (BDI) starting from vanillic acid -a lignin-derived phenolic acid. A series of partially bio-based aromatic polyimides containing 'twisted' biphenylene linkages was synthesized by polycondensation of BDI with five commercially available aromatic dianhydrides viz. 4,4'-oxydiphthalic anhydride 3,3',4,4'-benzophenonetetracarboxylic dianhydride, 4,4'(hexafluoroisopropylidene)diphthalic anhydride 4,4'-biphenyltetracarboxylic dianhydride and pyromellitic dianhydride. Polyimides were characterized by FT-IR, ${ }^{1} \mathrm{H}$ NMR, ${ }^{13} \mathrm{C}$ NMR spectroscopy, X-ray diffraction studies, thermogravimetric analysis (TGA) and differential scanning calorimetry (DSC). The effects of structure of dianhydride on solubility and thermal properties of polyimides were investigated. 


\section{Experimental}

\subsection{Materials}

Vanillic acid (97\%) and Laccase from Trametes versicolor $(0.5 \mathrm{U} / \mathrm{mg})$, were purchased from Sigma-Aldrich, USA. 4,4'-Oxydiphthalic anhydride (ODPA) 3,3',4,4'benzophenone tetracarboxylic dianhydride (BTDA), 4,4'-(hexafluoroisopropylidene) diphthalic anhydride (6FDA) 4,4'-biphenyltetracarboxylic dianhydride (BPDA) and pyromellitic dianhydride (PMDA) (Sigma Aldrich, USA) were sublimed before use. 1,4diazabicyclo[2.2.2] octane (DABCO) (Sigma Aldrich, USA) was recrystallized from nhexane. Methyl iodide, sodium acetate ( $\mathrm{NaOAc})$, sodium hydroxide, potassium carbonate, hydrochloric acid, sulphuric acid, sodium azide, ethyl chloroformate, triethyl amine and solvents were obtained from Thomas Baker (India) and were used as received. Toluene, $N, N$ dimethylacetamide (DMAc) and $N, N$-dimethylformamide (DMF) were dried over calcium hydride and distilled prior to use.

\subsection{Measurements}

Melting points were recorded on Electrothermal MEL-TEMP apparatus. FT-IR spectra were obtained on a Perkin-Elmer Spectrum GX spectrometer using KBr. NMR spectra were recorded on a Bruker 200,400 or $500 \mathrm{MHz}$ spectrometer at resonance frequencies of 200, 400 or $500 \mathrm{MHz}$ for ${ }^{1} \mathrm{H}$ NMR and $50,100,125 \mathrm{MHz}$ for ${ }^{13} \mathrm{C} \mathrm{NMR}$ measurements using $\mathrm{CDCl}_{3}$ or DMSO- $\mathrm{d}_{6}$ as a solvent. HR-MS were obtained on a Thermo Scientific Q-Exacative, Accela 1250 pump. Inherent viscosity of polyimides was measured with $0.5 \%(\mathrm{w} / \mathrm{v})$ solution of polymer in DMAc at $30 \pm 0.1^{\circ} \mathrm{C}$ using Ubbelhode suspended level viscometer. Molecular weights and dispersity values of polyimides were determined on Thermo-Finnigan make gel permeation chromatography (GPC) using DMF as an eluent at a flow rate of $1 \mathrm{~mL} \mathrm{~min}{ }^{-1}$ at $25{ }^{\circ} \mathrm{C}$. Sample concentration was $2 \mathrm{mg} \mathrm{mL}^{-1}$ and narrow dispersity polystyrenes were used as calibration standards. X-Ray diffraction patterns of polyimides were recorded using dried polymer film on a Rigaku Dmax 2500 X-ray diffractometer at a tilting rate of $2^{\circ} \mathrm{min}^{-1}$. Thermogravimetric analysis was carried out on Perkin Elmer: STA 6000 , at a heating rate of $10{ }^{\circ} \mathrm{C} \mathrm{min}^{-1}$ under nitrogen atmosphere. Differential scanning calorimetry was performed on TA Instruments DSC Q100 system at a heating rate $10{ }^{\circ} \mathrm{C} \mathrm{min}-$ ${ }^{1}$ under nitrogen atmosphere. 


\subsection{Synthesis of 5,5'-diisocyanato-2,2',3,3'-tetramethoxy-1,1'-biphenyl}

Synthesis of methyl 4-hydroxy-3-methoxybenzoate (1)

Into a $250 \mathrm{~mL}$ two-necked round bottom flask equipped with a reflux condenser and an argon inlet were charged vanillic acid $(8.4 \mathrm{~g}, 50 \mathrm{mmol})$, sulphuric acid $(1 \mathrm{~mL})$ and methanol $(100 \mathrm{~mL})$. The reaction mixture was refluxed for $12 \mathrm{~h}$. After completion of reaction, excess methanol was removed under reduced pressure. The reaction mixture was dissolved in dichloromethane $(100 \mathrm{~mL})$. The dichloromethane solution was washed with water $(2 \times 100 \mathrm{~mL})$, dried over anhydrous sodium sulfate, filtered, and concentrated under reduced pressure. The crude product was filtered through short bed of silica column using petroleum ether: dichloromethane as an eluent to afford white solid.

Yield 8.65g (95\%); FTIR (KBr): $1692 \mathrm{~cm}^{-1} ;{ }^{1} \mathrm{H}$ NMR (200 MHz, $\left.\mathrm{CDCl}_{3}, \delta / \mathrm{ppm}\right): 3.90$ (s, 3H), 3.95 (s, 3H), 6.05 (s, 1H), $6.94(\mathrm{~d}, 1 \mathrm{H}), 7.56$ (d, 1H), $7.66(\mathrm{dd}, 1 \mathrm{H}) ;{ }^{13} \mathrm{C} \mathrm{NMR}(50 \mathrm{MHz}$, $\left.\mathrm{CDCl}_{3}, \delta / \mathrm{ppm}\right): \quad 51.9,56.0,111.8,114.1,122.2,124.1,146.2,150.0,166.9$; HRMS (ESI) calculated for $\mathrm{C}_{9} \mathrm{H}_{10} \mathrm{O}_{4}(\mathrm{M}+\mathrm{H}), 183.0657$; found, 183.0652 .

Synthesis of dimethyl 6,6'-dihydroxy-5,5'-dimethoxy-[1,1'-biphenyl]-3,3'-dicarboxylate (2)

Into a $3 \mathrm{~L}$ two-necked round bottom flask were charged methyl vanillate (15 g, 82.3 mmol), NaOAc buffer $(1800 \mathrm{~mL}, 0.1 \mathrm{M}, \mathrm{pH} 5.0)$ and acetone $(200 \mathrm{~mL})$. The solution was saturated with $\mathrm{O}_{2}$ for $5 \mathrm{~min}$. Laccase from Trametes versicolor (124 mg) was added and the reaction mixture was stirred at room temperature for $24 \mathrm{~h}$. The precipitate was filtered off and the product was dried overnight at $90{ }^{\circ} \mathrm{C}$.

Yield 26.5g (89 \%); FTIR (KBr): 3432, $1716 \mathrm{~cm}^{-1} ;{ }^{1} \mathrm{H}$ NMR (200 MHz, $\mathrm{CDCl}_{3}, \delta / \mathrm{ppm}$ ): 3.80 (s, 6H), 3.89 (s, 6H), 7.45 (s, 4H), 9.68 (br. s, 2H); $\left.{ }^{13} \mathrm{C} \mathrm{NMR} \mathrm{(50} \mathrm{MHz,} \mathrm{CDCl}_{3}, \delta / \mathrm{ppm}\right): 51.7$, 56.0, 110.9, 119.2, 124.5, 125.4, 147.6, 149.3, 166.1; HRMS ESI ${ }^{+}:(\mathrm{M}+\mathrm{H})^{+} \mathrm{m} / \mathrm{z}$ calculated for $\mathrm{C}_{18} \mathrm{H}_{19} \mathrm{O}_{8}: 363.1074$, found: 363.1071 .

Synthesis of dimethyl 5,5',6,6'-tetramethoxy-[1,1'-biphenyl]-3,3'-dicarboxylate (3)

Into a $500 \mathrm{~mL}$ two-necked round bottom flask equipped with a reflux condenser and an argon inlet were charged, dimethyl 6,6'-dihydroxy-5,5'-dimethoxy-[1,1'-biphenyl]-3,3'dicarboxylate (8 g, $22.0 \mathrm{mmol})$, potassium carbonate (12.2 g, $88.3 \mathrm{mmol})$ and DMF (100 $\mathrm{mL})$. The reaction mixture was heated at $100{ }^{\circ} \mathrm{C}$ for $1 \mathrm{~h}$ and then methyl iodide $(7.8 \mathrm{~g}, 55.2$ mmol) was added and heating was continued for $12 \mathrm{~h}$. The reaction mixture was poured into ice cold water $(1000 \mathrm{~mL})$. The precipitate was filtered, dried and dissolved in dichloromethane $(100 \mathrm{~mL})$. The dichloromethane solution was washed with water $(2 \times 500$ 
$\mathrm{mL}$ ), dried over anhydrous sodium sulfate, filtered, and concentrated under reduced pressure. The crude product was purified by column chromatography using petroleum ether: ethyl acetate $(70: 30 \mathrm{v} / \mathrm{v})$ as an eluent to afford a white solid.

Yield 7.8g (91 \%); FTIR (KBr): $1725 \mathrm{~cm}^{-1} ;{ }_{1}^{1} \mathrm{H}$ NMR (200 MHz, $\left.\mathrm{CDCl}_{3}, \delta / \mathrm{ppm}\right): 3.72$ (s, 6H), $3.89(\mathrm{~s}, 6 \mathrm{H}), 3.96(\mathrm{~s}, 6 \mathrm{H}), 7.58(\mathrm{~d}, 2 \mathrm{H}), 7.63$ (d, 2H); ${ }^{13} \mathrm{C} \mathrm{NMR}\left(50 \mathrm{MHz}, \mathrm{CDCl}_{3}, \delta / \mathrm{ppm}\right)$ : 52.1, 56.0, 60.8, 113.0, 125.0, 125.1, 131.7, 150.9, 152.4, 166.6; HRMS ESI ${ }^{+}:(\mathrm{M}+\mathrm{H})^{+} \mathrm{m} / \mathrm{z}$ calculated for $\mathrm{C}_{20} \mathrm{H}_{23} \mathrm{O}_{8}: 391.1387$, found: 391.1383 .

Synthesis of 5,5',6,6'-tetramethoxy-[1,1'-biphenyl]-3,3'-dicarboxylic acid (4)

Into a $500 \mathrm{~mL}$ two-necked round bottom flask equipped with a reflux condenser were charged dimethyl 5,5',6,6'-tetramethoxy-[1,1'-biphenyl]-3,3'-dicarboxylate (11.7 g, $30 \mathrm{mmol})$, sodium hydroxide $(6 \mathrm{~g}, 150 \mathrm{mmol})$, methanol $(100 \mathrm{~mL})$ and water $(100 \mathrm{~mL})$. The reaction mixture was refluxed for $12 \mathrm{~h}$ and then methanol was removed under reduced pressure. The solution was diluted with water and acidified with aqueous hydrochloric acid (3M). The precipitate was filtered and dried in vacuum oven at $60{ }^{\circ} \mathrm{C}$ for $4 \mathrm{~h}$ and then recrystallized from aqueous ethanol.

Yield 10.3g (95\%); FTIR (KBr): $1671 \mathrm{~cm}^{-1} ;{ }^{1} \mathrm{H}$ NMR (200 MHz, $\left.\mathrm{CDCl}_{3}, \delta / \mathrm{ppm}\right): 3.61$ (s, $6 \mathrm{H}), 3.91(\mathrm{~s}, 6 \mathrm{H}), 7.38(\mathrm{~d}, 2 \mathrm{H}), 7.57(\mathrm{~d}, 2 \mathrm{H}), 12.95(\mathrm{~s}, 2 \mathrm{H}) ;{ }^{13} \mathrm{C} \mathrm{NMR}\left(50 \mathrm{MHz}, \mathrm{CDCl}_{3}\right.$, $\delta / \mathrm{ppm}): 55.8,60.2,112.9,124.1,125.9,131.3,150.0,152.1,166.8 ; \mathrm{HRMS} \mathrm{ESI}^{+}:(\mathrm{M}+\mathrm{Na})^{+}$ $\mathrm{m} / \mathrm{z}$ calculated for $\mathrm{C}_{18} \mathrm{H}_{18} \mathrm{O}_{8} \mathrm{Na}$ : 385.0894 , found: 385.0892 .

\section{Synthesis of 5,5',6,6'-tetramethoxy-[1,1'-biphenyl]-3,3'-dicarbonyl diazide (5)}

Into a $250 \mathrm{~mL}$ two-necked round bottom flask equipped with a reflux condenser, an argon inlet and an addition funnel were charged, 5,5',6,6'-tetramethoxy-[1,1'-biphenyl]-3,3'dicarboxylic acid $(7.2 \mathrm{~g}, 20 \mathrm{mmol})$ and a mixture of tetrahydrofuran: water $(3: 1 \mathrm{v} / \mathrm{v}, 100 \mathrm{~mL})$. The reaction mixture was cooled to $0{ }^{\circ} \mathrm{C}$ and the solution of triethyl amine (12 g, $\left.120 \mathrm{mmol}\right)$ in tetrahydrofuran $(20 \mathrm{~mL})$ was added drop wise over a period of $15 \mathrm{~min}$. To the reaction mixture, ethylchloroformate $(12.8 \mathrm{~g}, 120 \mathrm{mmol})$ was added dropwise over a period of $10 \mathrm{~min}$ and stirred for $2 \mathrm{~h}$. The solution of sodium azide $(7.8 \mathrm{~g}, 160 \mathrm{mmol})$ in water $(30 \mathrm{~mL})$ was added drop-wise over a period of $10 \mathrm{~min}$ and the reaction mixture was stirred at $0{ }^{\circ} \mathrm{C}$ for $2 \mathrm{~h}$ and then at $25{ }^{\circ} \mathrm{C}$ for $4 \mathrm{~h}$. Ice cold water $(250 \mathrm{~mL})$ was added gradually to the reaction mixture and solid was precipitated out. The precipitate was filtered and washed with water. The product was dissolved in dichloromethane $(200 \mathrm{~mL})$ and washed with water $(150 \mathrm{~mL})$, 
dried over anhydrous sodium sulfate, filtered, and concentrated under reduced pressure at 25 ${ }^{\circ} \mathrm{C}$ to afford a white solid.

Yield 6.5g (80 \%); FTIR (KBr): 2143, $1680 \mathrm{~cm}^{-1} ;{ }^{1} \mathrm{H}$ NMR (200 MHz, $\left.\mathrm{CDCl}_{3}, \delta / \mathrm{ppm}\right): 3.75$ (d, 6H), $3.96(\mathrm{~d}, 6 \mathrm{H}), 7.55(\mathrm{~s}, 2 \mathrm{H}), 7.61(\mathrm{~s}, 2 \mathrm{H}) ;{ }^{13} \mathrm{C} \mathrm{NMR}\left(50 \mathrm{MHz}, \mathrm{CDCl}_{3}, \delta / \mathrm{ppm}\right): 55.9$, $60.8,112.5,124.9,125.5,131.4,152.1,152.5,171.5$; HRMS ESI ${ }^{+}:(\mathrm{M}+\mathrm{H})^{+} \mathrm{m} / \mathrm{z}$ calculated for $\mathrm{C}_{18} \mathrm{H}_{17} \mathrm{~N}_{6} \mathrm{O}_{8}$ : 413.1204, found: 413.2663 .

\section{Synthesis of 5,5'-diisocyanato-2,2',3,3'-tetramethoxy-1,1'-biphenyl (BDI)}

Into a $100 \mathrm{~mL}$ two-necked round bottom flask equipped with a reflux condenser and a nitrogen inlet were charged, 5,5',6,6'-tetramethoxy-[1,1'-biphenyl]-3,3'-dicarbonyl diazide $(1.9 \mathrm{~g}, 4.69 \mathrm{mmol})$ and dry toluene $(25 \mathrm{~mL})$. The reaction mixture was heated at $80{ }^{\circ} \mathrm{C}$ for 8 h. The toluene was removed under reduced pressure at $60{ }^{\circ} \mathrm{C}$ and white solid compound was obtained.

Yield 1.4g (85\%); FTIR (KBr): $2268 \mathrm{~cm}^{-1}$; ${ }^{1} \mathrm{H}$ NMR (200 MHz, $\left.\mathrm{CDCl}_{3}, \delta / \mathrm{ppm}\right): 3.66$ (d, $6 \mathrm{H}), 3.90$ (d, 6H), 6.61 (s, 2H), 6.67 (s, 2H); $\left.{ }^{13} \mathrm{C} \mathrm{NMR} \mathrm{(50} \mathrm{MHz,} \mathrm{CDCl}_{3}, \delta / \mathrm{ppm}\right): 56.0,60.8$, $108.7,118.7,124.5,128.6,132.3,144.6,153.2 ; \mathrm{HRMS} \mathrm{ESI}^{+}:(\mathrm{M}+\mathrm{H})^{+} \mathrm{m} / \mathrm{z}$ calculated for $\mathrm{C}_{18} \mathrm{H}_{17} \mathrm{~N}_{2} \mathrm{O}_{6}$ : 357.1081, found: 357.1079.

\subsection{Synthesis of polyimides}

A representative procedure for the synthesis of polyimides is described below:

Into a $50 \mathrm{~mL}$ two necked round bottom flask equipped with a magnetic stirrer bar, a nitrogen inlet and a reflux condenser were taken BDI (1 g, $2.8 \mathrm{mmol})$, aromatic dianhydride (2.8 mmol), DABCO (94 mg, $0.84 \mathrm{mmol})$ and benzonitrile $(10 \mathrm{~mL})$. The reaction mixture was heated at $140{ }^{\circ} \mathrm{C}$ for $10 \mathrm{~h}$ under nitrogen atmosphere. The reaction mixture was cooled to room temperature and poured into excess methanol and the precipitated polymer was filtered, washed with hot methanol and dried at $100{ }^{\circ} \mathrm{C}$ for $10 \mathrm{~h}$ under reduced pressure.

Synthesis of PI-1 by polycondensation of BDI with ODPA


$6 \mathrm{H}), 3.92$ (s, 6H), 7.00 (s, 4H), 7.45 (d, 2H), 7.97 (d, 2H); ${ }^{13} \mathrm{C}$ NMR (125 MHz, DMSO-d 6 , $\delta / \mathrm{ppm}): 55.9,60.3,112.0,113.6,121.5,124.9,126.1,127.2,131.5,134.5,145.9,152.5$, $160.8,166.1,166.3$. 
Synthesis of PI-2 by polycondensation of BDI with 6-FDA

FT-IR (KBr): 736, 1375, 1731, $1771 \mathrm{~cm}^{-1} ;{ }^{1} \mathrm{H}$ NMR (500 MHz, DMSO-d 6 , $\left.\delta / \mathrm{ppm}\right): 3.65$ (s, $6 \mathrm{H}), 3.82(\mathrm{~s}, 6 \mathrm{H}), 6.92(\mathrm{~s}, 2 \mathrm{H}), 7.21(\mathrm{~s}, 2 \mathrm{H}), 7.73(\mathrm{~s}, 2 \mathrm{H}), 7.95(\mathrm{~d}, 2 \mathrm{H}), 8.16(\mathrm{~d}, 2 \mathrm{H}) ;{ }^{13} \mathrm{C}$ NMR (125 MHz, DMSO-d 6 , $\delta / p p m): 55.9,60.3,112.1,121.6,123.6,124.4,126.8,131.5$, 132.6, 133.0, 135.8, 137.3, 146.1, 152.5, 166.0, 166.2.

Synthesis of PI-3 by polycondensation of BDI with BTDA

FT-IR (KBr): 723, 1378, 1725, $1780 \mathrm{~cm}^{-1} ;{ }^{1} \mathrm{H}$ NMR (400 MHz, DMSO-d 6 , $\left./ \mathrm{ppm}\right): 3.67$ (s, $6 \mathrm{H}), 3.84$ (s, 6H), 6.95 (s, 2H), 7.24 (s, 2H), 8.13 (s, 2H), 8.22 (br. d, 4H); ${ }^{13} \mathrm{C}$ NMR (125 MHz, DMSO-d 6 , $\delta$ ppm): 56.1, 60.3, 112.0, 121.5, 123.8, 129.5, 131.5, 132.2, 134.8, 141.6, $146.0,152.5,166.3,193.4$

Synthesis of PI-4 by polycondensation of BDI with BPDA

FT-IR (KBr): 739, 1378, 1721, $1775 \mathrm{~cm}^{-1} ;{ }^{1} \mathrm{H}$ NMR (400 MHz, DMSO-d 6 , $/ \mathrm{ppm}$ ); 3.70 (s, $6 \mathrm{H}), 3.87$ (s, 6H), 6.97 (s, 2H), 7.23 (s, 2H), 8.03 (s, 2H), 8.3 (br. s, 4H); ${ }^{13} \mathrm{C}$ NMR (125 MHz, DMSO-d 6 , $\delta$ ppm): 55.1, 59.9, 111.8, 113.3, 121.1, 124.5, 125.9, 127.0, 131.1, 134.6, $145.8,152.3,160.2,166.0,165.5$

Synthesis of PI-5 by polycondensation of BDI with PMDA

FT-IR (KBr): 725, 1378, 1727, $1784 \mathrm{~cm}^{-1}$; ${ }^{1} \mathrm{H}$ NMR (400 MHz, DMSO-d 6 , $\left.\delta / p p m\right) ; 3.68$ (s, $6 \mathrm{H}), 3.85(\mathrm{~s}, 6 \mathrm{H}), 7.0(\mathrm{~s}, 2 \mathrm{H}), 7.27(\mathrm{~s}, 2 \mathrm{H}), 8.35(\mathrm{~s}, 2 \mathrm{H}) ;{ }^{13} \mathrm{C}$ NMR (125 MHz, DMSO-d 6 , $\delta / \mathrm{ppm}): 56.0,60.3,112.0,117.8,121.5,126.7,131.5,137.1,146.1,152.5,165.5$.

\section{Results and discussion}

\subsection{Synthesis of biphenylene-containing diisocyanate}

Aromatic diisocyanates are useful class of monomers in polymer industry, as they find applications in the synthesis of various step-growth polymers such as polyurethanes, polyureas, polyimides, polyamides and so on. More than $90 \%$ market of diisocyanates is captured by aromatic diisocyanates. The most commonly used aromatic diisocyanates viz. toluene diisocyanate and methylenediphenyl diisocyanate are obtained from petroleumderived chemicals. The reports on the synthesis of aromatic diisocyanates based on bioderived chemicals are scanty except for furan derivatives viz. 2,5-diisocyanatofuran, bis(5isocyanatofurfuryl)ether, diisocyanates containing difurylalkane moieties and CNSL-based diisocyanates $[10,11,38,39]$ 
In the present work, a new bio-based diisocyanate viz. 5,5'-diisocyanato-2,2',3,3'tetramethoxy-1,1'-biphenyl (BDI) was designed and synthesized starting from vanillic acid as depicted in Scheme 1.
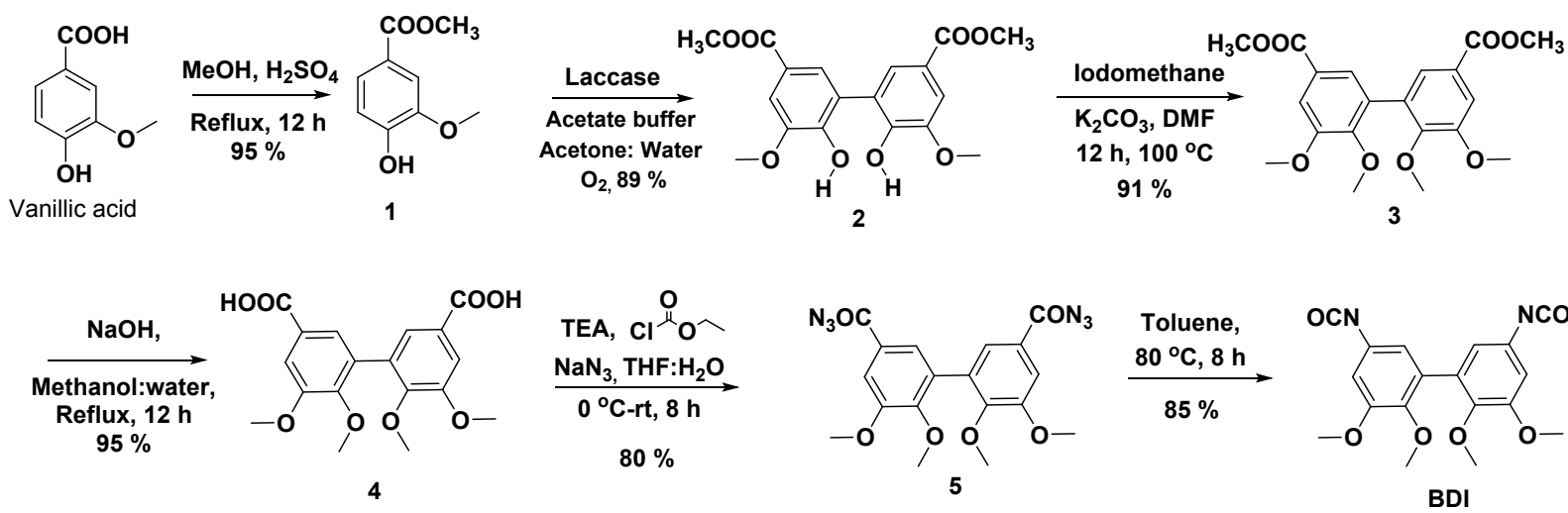

Scheme 1 Synthesis of biphenylene-containing diisocyanate starting from vanillic acid

In the first step, esterification of vanillic acid was carried out using methanol and catalytic amount of sulphuric acid to give methyl vanillate (1) which was subsequently dimerized using Laccase from Trametes versicolor as a catalyst in $\mathrm{NaOAc}$ buffer solution in acetone-water mixture ( $\mathrm{pH}$ 5.0) [40,41]. The resulting diester 2 was alkylated by using iodomethane in the presence of potassium carbonate in DMF to afford methyl protected diester 3. The hydrolysis of diester 3 by using sodium hydroxide in water: methanol mixture afforded diacid 4. Diacylazide 5 was synthesized from diacid 4 by elegant one-pot Weinstock modification of the Curtius rearrangement. In this reaction, diacid 4 was treated successively with triethylamine, ethylchloroformate and sodium azide. The obtained diacyl azide 5 was converted into BDI by heating at $80{ }^{\circ} \mathrm{C}$ for $8 \mathrm{~h}$ in toluene via thermal Curtius rearrangement. The reaction was monitored by FT-IR spectroscopy. The disappearance of the band at 2143 $\mathrm{cm}^{-1}$ and $1680 \mathrm{~cm}^{-1}$ corresponding to azido and carbonyl group indicated the complete conversion of azido carbonyl into isocyanato group (Figure-1). The chemical structure of diisocyanate was established by FT-IR, ${ }^{1} \mathrm{H}$ NMR, ${ }^{13} \mathrm{C}$ NMR spectroscopy and HRMS. In FTIR spectrum of BDI (Figure 1), the strong absorption band was observed at $2268 \mathrm{~cm}^{-1}$ corresponding to isocyanato group. 




Figure 1 FT-IR spectrum of 5,5'-diisocyanato-2,2',3,3'-tetramethoxy-1,1'-biphenyl

${ }^{1} \mathrm{H}$ NMR spectrum of BDI is displayed in Figure 2. The aromatic protons exhibited two doublets at $\delta=6.67 \mathrm{ppm}$ and $6.60 \mathrm{ppm}$ corresponding to proton 'a' and 'b', respectively. Methoxyl group protons meta and para to isocyanato group exhibited two separate singlets at $3.90 \mathrm{ppm}$ and $3.66 \mathrm{ppm}$, respectively. ${ }^{13} \mathrm{C}$ NMR spectrum of BDI along with the assignments is shown in Figure 3.
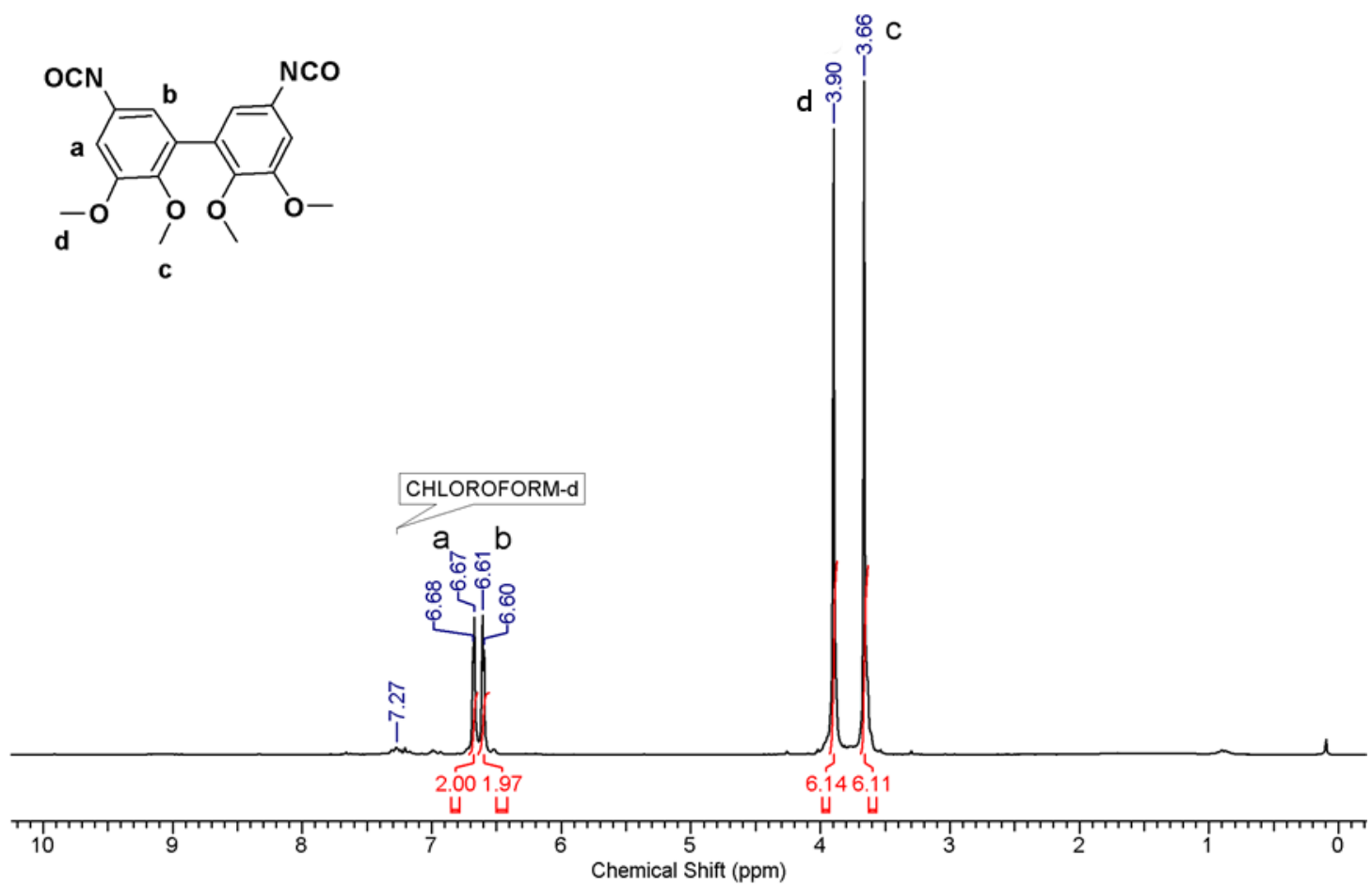

Figure $2{ }^{1} \mathrm{H}$ NMR spectrum of 5,5'-diisocyanato-2,2',3,3'-tetramethoxy-1,1'-biphenyl. 


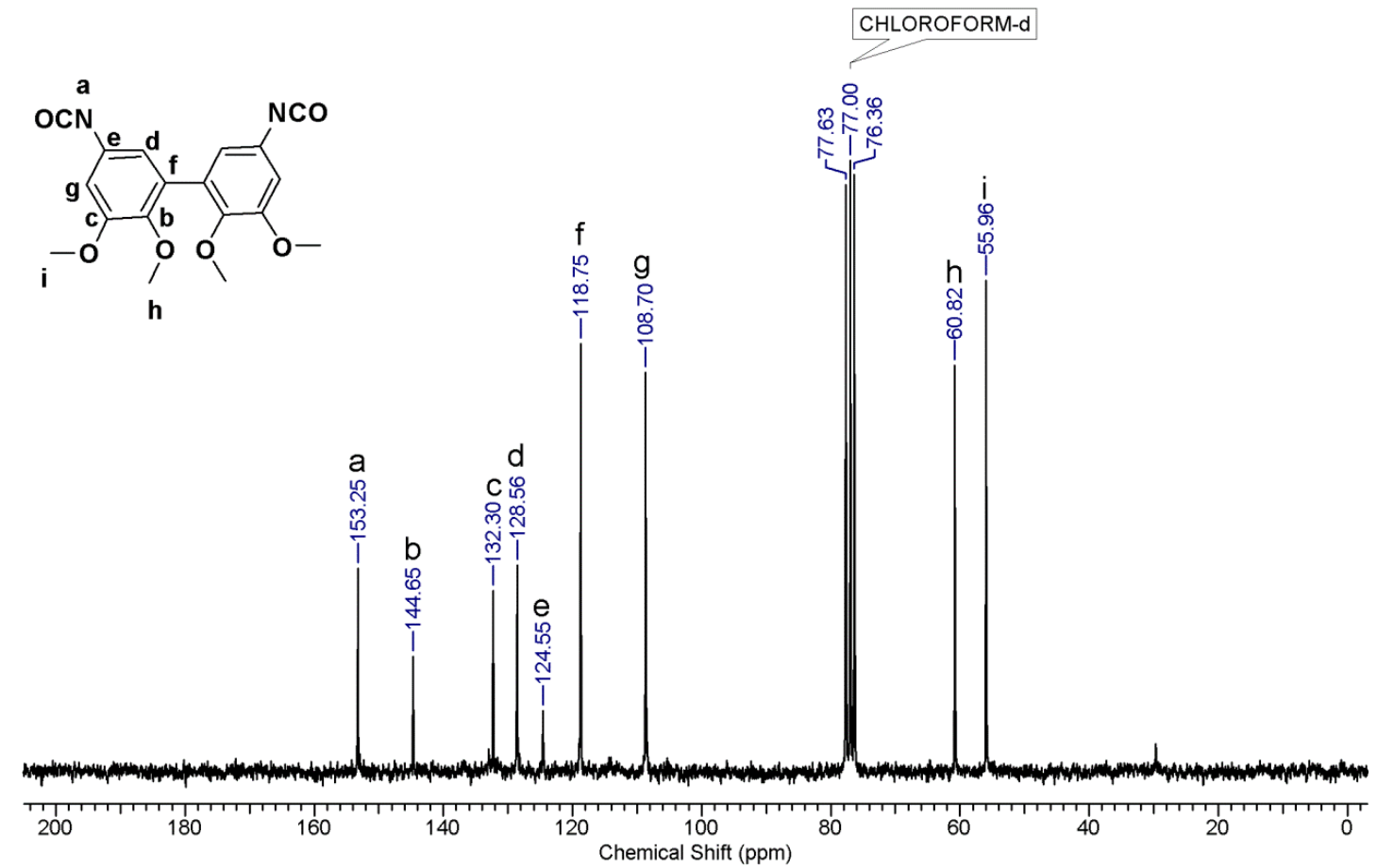

Figure $3{ }^{13} \mathrm{C}$ NMR spectrum of 5,5'-diisocyanato-2,2',3,3'-tetramethoxy-1,1'-biphenyl

\subsection{Polyimide synthesis}

A series of new partially bio-based polyimides containing 'twisted' biphenylene linkages were synthesized by polycondensation of BDI with aromatic dianhydrides viz. 4,4'oxydiphthalic anhydride (ODPA), 3,3',4,4'-benzophenonetetracarboxylic dianhydride (BTDA), 4,4'(hexafluoroisopropylidene)diphthalic anhydride (6FDA), 4,4'biphenyltetracarboxylic dianhydride (BPDA) and pyromellitic dianhydride (PMDA) using $\mathrm{DABCO}$ as the catalyst in benzonitrile at $140{ }^{\circ} \mathrm{C}$ (Scheme 2). In this reaction, BDI and dianhydride reacted together to form seven-membered cyclic intermediate, which thermally decomposed to form polyimide with evolution of carbon dioxide. The reaction mixture was homogenous throughout the course of polymerization.



Scheme 2 Synthesis of biphenylene-containing polyimides by polycondensation of BDI with aromatic dianhydrides 
Table 1 Synthesis of aromatic polyimides derived from 5,5'-diisocyanato-2,2',3,3'tetramethoxy-1,1'-biphenyl (BDI) and aromatic dianhydrides

\begin{tabular}{|c|c|c|c|c|c|c|c|c|}
\hline \multirow[b]{2}{*}{ Code } & \multirow[b]{2}{*}{ Polyimide } & \multirow[b]{2}{*}{$\begin{array}{c}\eta_{\text {inh }} \\
\left(\mathrm{dLg}^{-1}\right)^{\mathrm{a}}\end{array}$} & \multicolumn{3}{|c|}{$\mathrm{GPC}^{\mathrm{b}}$} & \multicolumn{3}{|c|}{ Char } \\
\hline & & & $\begin{array}{c}\mathrm{M}_{\mathrm{n}} \\
\mathrm{g} / \mathrm{mol}\end{array}$ & $\begin{array}{c}\mathrm{M}_{\mathrm{w}} \\
\mathrm{g} / \mathrm{mol}\end{array}$ & Dispersity & $\begin{array}{l}\mathrm{T}_{10}{ }^{\mathrm{c}} \\
\left({ }^{\circ} \mathrm{C}\right)\end{array}$ & $\begin{array}{c}\text { at } 800 \\
{ }^{\circ} \mathrm{C}\end{array}$ & $\begin{array}{l}\mathrm{T}_{\mathrm{g}}^{\mathrm{d}} \\
\left({ }^{\circ} \mathrm{C}\right)\end{array}$ \\
\hline
\end{tabular}

$(\%)$

(2)

a $\eta_{\text {inh }}$ was measured with $0.5 \%(\mathrm{w} / \mathrm{v})$ solution of polyimide in DMAc at $30^{\circ} \mathrm{C} \pm 0.1^{\circ} \mathrm{C}$.

b Measured by GPC in DMF, polystyrene was used as the calibration standard.

c Temperature at which $10 \%$ weight loss was observed.

d $\mathrm{T}_{\mathrm{g}}$ determined by DSC

ns GPC measurements could not be carried out due to insolubility of polymer in DMF 
The results of polymerization reactions are summarized in Table 1. Inherent viscosity values and number average molecular weights of polyimides were in the range $0.30-0.40 \mathrm{dLg}^{-1}$ and 25,100-32,200 $\mathrm{g} \mathrm{mol}^{-1}$, respectively. The results of GPC and inherent viscosity measurements indicated the formation of medium molecular weight polymers. Molecular weight of polyimide derived from BDI and BPDA could not be measured due its partial solubility in DMF.

\subsection{Structural characterization}

The chemical structure of polyimides was confirmed by FT-IR, ${ }^{1} \mathrm{H}$ NMR and ${ }^{13} \mathrm{C}$ NMR spectroscopy. A representative FT-IR spectrum of PI-5 is presented in Figure 4.

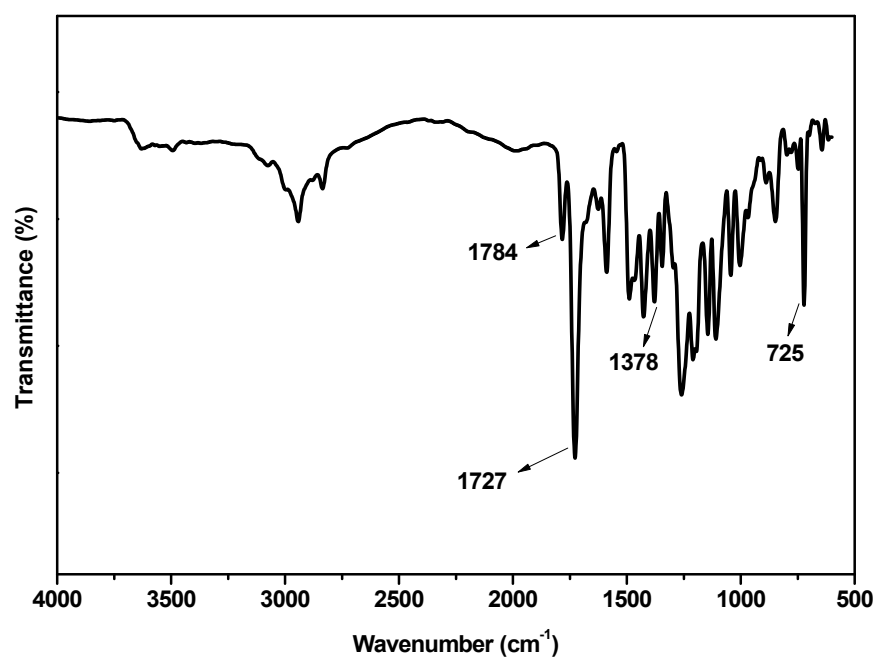

Figure 4 FT-IR spectrum of polyimide (PI-5) derived from BDI and aromatic dianhydride

The characteristic absorption bands for imide ring were observed at $1784 \mathrm{~cm}^{-1}$ and $1727 \mathrm{~cm}^{-1}$ which correspond to asymmetric and symmetric carbonyl stretching, respectively. Absorption band at $1378 \mathrm{~cm}^{-1}$ corresponds to C-N stretching and absorption band at $725 \mathrm{~cm}^{-1}$ was ascribed to imide ring deformation.

A representative ${ }^{1} \mathrm{H}$ NMR spectrum of polyimide derived from BDI and PMDA is shown in Figure 5. Aromatic protons of dianhydride moiety showed a singlet at $\delta=8.35$ ppm. The two singlets appeared at $7.27 \mathrm{ppm}$ and $7.0 \mathrm{ppm}$ are attributed to proton labeled as 'b' and 'c', respectively. Methoxy protons meta and para to imide nitrogen showed singlet at $3.85 \mathrm{ppm}$ and $3.68 \mathrm{ppm}$, respectively.

${ }^{13} \mathrm{C}$ NMR spectrum of polyimide (PI-5) derived from BDI and PMDA is shown in Figure 6 along with the assignments. 


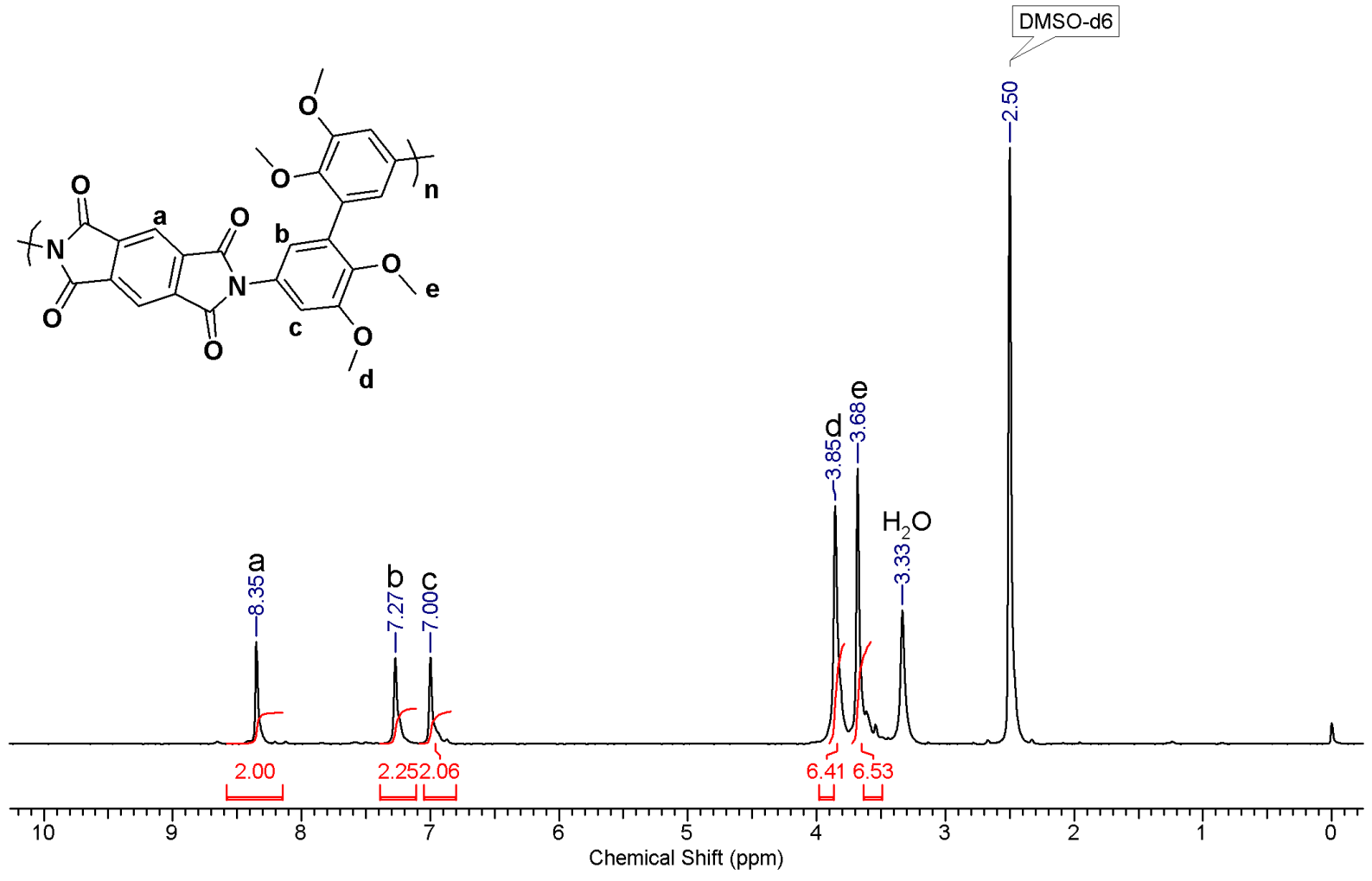

Figure $5{ }^{1} \mathrm{H}$ NMR spectrum of polyimide (PI-5) derived from BDI and PMDA in DMSO-d 6<smiles></smiles>

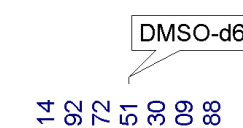




Figure $6{ }^{13} \mathrm{C}$ NMR spectrum of polyimide (PI-5) derived from BDI and PMDA in DMSO-d 6 . 


\subsection{Solubility of polyimides}

The solubility of polyimides was tested at $3 \mathrm{wt} \%(\mathrm{w} / \mathrm{v})$ concentration in various organic solvents and the data is summarized in Table 2.

Table 2 Solubility data of polyimides derived from BDI and aromatic dianhydrides.

\begin{tabular}{|c|c|c|c|c|c|c|c|c|}
\hline 兽 & 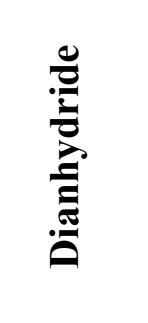 & 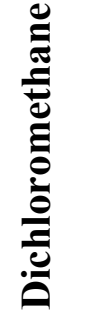 & 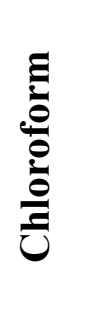 & $\sum_{i}^{L}$ & $\sum_{i}^{e}$ & $\hat{z}$ & $\sum_{i}^{0}$ &  \\
\hline PI-1 & ODPA & ++ & ++ & ++ & ++ & ++ & ++ & ++ \\
\hline PI-2 & $6 \mathrm{FDA}$ & ++ & ++ & ++ & ++ & ++ & ++ & ++ \\
\hline PI-3 & BTDA & -- & -- & ++ & ++ & ++ & ++ & ++ \\
\hline PI-4 & BPDA & -- & -- & -- & ++ & ++ & ++ & ++ \\
\hline PI-5 & PMDA & -- & -- & ++ & ++ & ++ & ++ & ++ \\
\hline
\end{tabular}

++ : soluble at room temperature; -- : insoluble at room temperature.

All the polyimides were soluble in polar organic solvents such as DMSO, DMAc, NMP and pyridine at room temperature. The solubility of biphenylene-containing polyimides could be ascribed to the zig-zag structure and the presence of methoxy groups which bring about disordering in the packing of the polymer chains. In addition, polyimides derived from 6FDA and ODPA were also soluble in halogenated solvents such as chloroform and dichloromethane. In case of 6FDA-based polyimide (PI-2), the presence of bulky $\mathrm{CF}_{3}$ substituents, which increased the disorder in the chains and hindered close packing thereby decreasing the intermolecular interactions, is the cause of further enhancement in solubility characteristics [42]. ODPA-derived polyimide (PI-1) showed excellent solubility due to the presence of flexible ether linkages in the polymer backbone.

\subsection{X-Ray diffraction studies}

X-Ray diffractograms of polyimide films based on BDI and aromatic dianhydrides are reproduced in Figure 7. X-Ray diffractograms of polyimides showed a broad halo at around $2 \theta=10-30^{\circ}$ suggesting that all the polymers were amorphous. The amorphous nature of polyimides could be attributed to the presence of methoxy substituents situated at the meta 
and para position to the nitrogen of imide group and the zig-zag structure. These structural features decrease interchain interactions thus disturbing the chain packing.

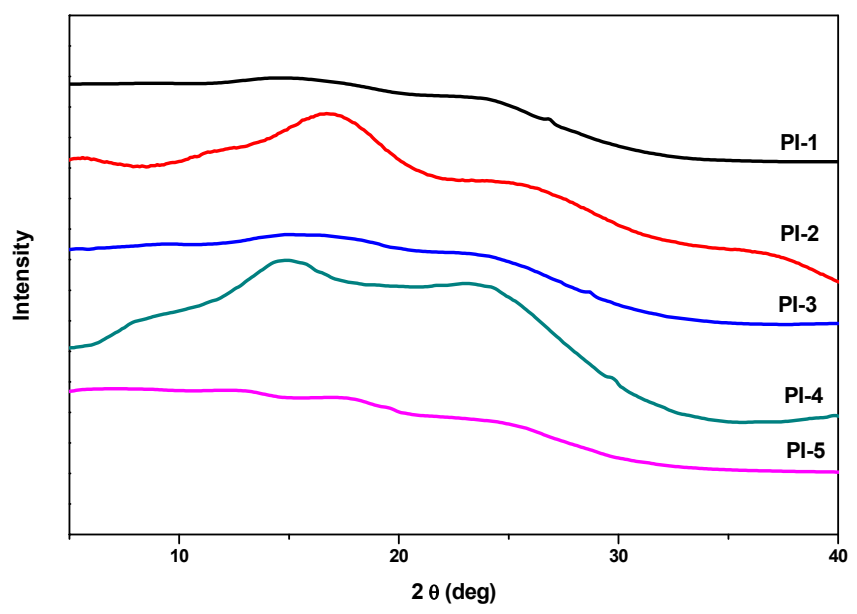

Figure 7 X-Ray diffractograms of polyimides derived from BDI and aromatic dianhydrides

\subsection{Thermal properties of polyimides}

Thermal characteristics of polyimides were evaluated by TGA and DSC at heating rate of $10{ }^{\circ} \mathrm{C} \mathrm{min}-1$ under nitrogen atmospheres. TG and DSC curves are shown in Figure 8 and Figure 9, respectively and results are summarized in Table 1.

Polyimides showed $10 \%$ wt. loss and char yield at $800{ }^{\circ} \mathrm{C}$ in the range $459-473{ }^{\circ} \mathrm{C}$ and $45-55 \%$, respectively. A representative differential thermogravimetric (DTG) analysis curve of polyimide PI-2 is included in Figure 8. DTG curves of polyimides indicated twostage degradation: the first stage degradation was presumably due to the cleavage of methoxy groups whereas the second stage degradation was observed due to decomposition of polyimide backbone.

It is interesting to compare the char yields of polyimides. In the series of polyimides, polyimide based on 6FDA (PI-2) showed the lowest char yield (45\%). This could be due to the less thermally stable $-\mathrm{C}\left(\mathrm{CF}_{3}\right)_{2^{-}}$group, which gets lost in the form of $\mathrm{CF}_{3}$ radicals [43]. Polyimide based on BPDA (PI-4) showed highest char yield (55\%) which is in line with its highest aromatic character. 


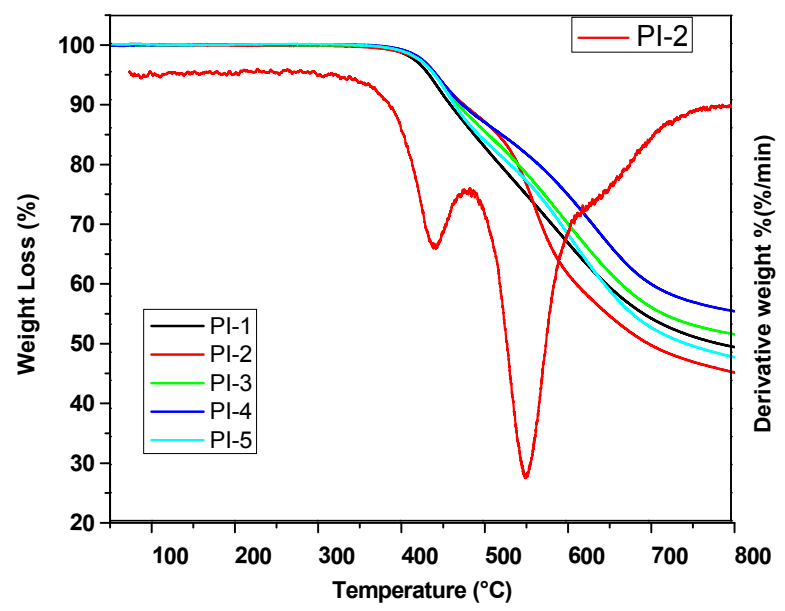

Figure 8 TG curves of polyimides derived from BDI and aromatic dianhydrides and DTG curve of PI-2.

$\mathrm{T}_{\mathrm{g}}$ values of polyimides were in the range $262-329{ }^{\circ} \mathrm{C}$ and the order is: ODPA $<6$ FDA $<$ BTDA $<$ BPDA $<$ PMDA. Generally, the $T_{g}$ value increases with increasing the chain rigidity of the polymer[44]. Therefore, highest $\mathrm{T}_{\mathrm{g}}$ value $\left(329^{\circ} \mathrm{C}\right)$ was observed for polyimide (PI-5) based on PMDA due to highly rigid backbone. On the other hand, lowest $\mathrm{T}_{\mathrm{g}}$ value $\left(262{ }^{\circ} \mathrm{C}\right)$ was logically observed for polyimide (PI-1) based on ODPA due to the presence of flexibilizing ether linkages [42].

Overall, the results of polyimide synthesis and their properties indicated that BDI is a welcome addition to the family of bio-based difunctional monomers suitable for the synthesis of organo-soluble aromatic polyimides with satisfactory thermal properties.

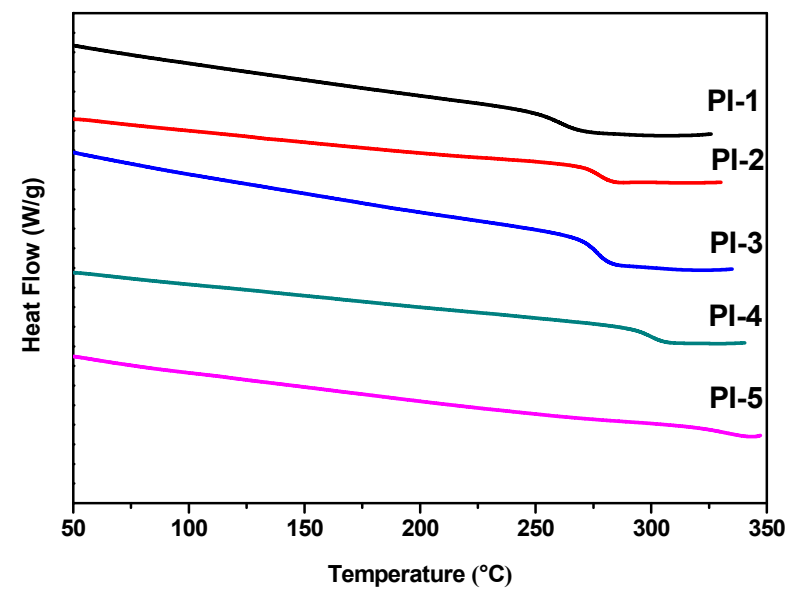

Figure 9 DSC curves of polyimides derived from BDI and aromatic dianhydrides 


\section{Conclusions}

A new aromatic diisocyanate, namely, 5,5'-diisocyanato-2,2',3,3'-tetramethoxy-1,1'biphenyl (BDI) was synthesized starting from vanillic acid and was polycondesed with five commercially available aromatic dianhydrides to obtain a series of partially bio-based polyimides. Polyimides displayed medium molecular weights and good solubility in organic solvents. $\mathrm{T}_{10}$ and $\mathrm{T}_{\mathrm{g}}$ values of polyimides were in the range $459-473{ }^{\circ} \mathrm{C}$ and $262-329{ }^{\circ} \mathrm{C}$, respectively indicating their good thermal properties. The biphenylene-containing polyimides could be considered as promising high performance bio-based materials.

\section{Acknowledgements}

S.S.K. gratefully acknowledges the University Grants Commission (UGC), New Delhi, India for the fellowship. A.B.I. would like to thank the Council of Scientific and Industrial Research (CSIR), India and Centre national de la recherche scientifique (CNRS), France for the fellowship.

\section{References}

[1] D.-J. Liaw, K.-L. Wang, Y.-C. Huang, K.-R. Lee, J.-Y. Lai, C.-S. Ha, Advanced polyimide materials: Syntheses, physical properties and applications, Prog. Polym. Sci. 37 (2012) 907-974. doi:10.1016/j.progpolymsci.2012.02.005.

[2] K.S.Y. Lau, High-Performance Polyimides and High Temperature Resistant Polymers, in: Handbook of Thermoset Plastics., Third Ed., Elsevier, 2014: pp. 297-424. doi:10.1016/B978-1-4557-3107-7.00010-5.

[3] M. Ding, Isomeric polyimides, Prog. Polym. Sci. 32 (2007) 623-668. doi:10.1016/j.progpolymsci.2007.01.007.

[4] M.G. Dhara, S. Banerjee, Fluorinated high-performance polymers: Poly(arylene ether)s and aromatic polyimides containing trifluoromethyl groups, Prog. Polym. Sci. 35 (2010) 1022-1077. doi:10.1016/j.progpolymsci.2010.04.003.

[5] M. Hasegawa, Development of solution-processable, optically transparent polyimides with ultra-low linear coefficients of thermal expansion, Polymers. 9 (2017) 520. doi:10.3390/polym9100520. 
[6] N. V. Sadavarte, M.R. Halhalli, C.V. Avadhani, P.P. Wadgaonkar, Synthesis and characterization of new polyimides containing pendent pentadecyl chains, Eur. Polym. J. 45 (2009) 582-589. doi:10.1016/j.eurpolymj.2008.11.013.

[7] C.-S. Wang, T.-S. Leu, Synthesis and characterization of polyimides containing naphthalene pendant group and flexible ether linkages, Polymer. 41 (2000) 35813591. doi:10.1016/S0032-3861(99)00613-8.

[8] A.E. Lozano, J.G. de La Campa, J. de Abajo, Aromatic polyamides and polyimides derived from 3,3'-diaminobiphenyl: Synthesis, characterization, and molecular simulation study, J. Polym. Sci. Part A Polym. Chem. 37 (1999) 4646-4655. doi:10.1002/(SICI)1099-0518(19991215)37:24<4646::AID-POLA23>3.0.CO;2-K.

[9] R.D. Shingte, B. V. Tawade, P.P. Wadgaonkar, Partially biobased processable polyimides based on aromatic diamine derived from cardanol, Green Mater. 5 (2017) 74-84. doi:10.1680/jgrma.17.00010.

[10] C. Voirin, S. Caillol, N. V. Sadavarte, B. V. Tawade, B. Boutevin, P.P. Wadgaonkar, Functionalization of cardanol: towards biobased polymers and additives, Polym. Chem. 5 (2014) 3142-3162. doi:10.1039/C3PY01194A.

[11] D. Chatterjee, N. V. Sadavarte, R.D. Shingte, A.S. More, B. V. Tawade, A.D. Kulkarni, A.B. Ichake, C. V. Avadhani, P.P. Wadgaonkar, Step-growth polymers from cashew nut shell liquid (CNSL)-based aromatic difunctional monomers, in: Parambath Anilkumar (Ed.), Cashew Nut Shell Liquid: a Goldfield for Functional Materials., 1st ed., Springer International Publishing, Cham, 2017: pp. 163-214. doi:10.1007/978-3319-47455-7_9.

[12] M.-D. Damaceanu, C.-P. Constantin, A. Nicolescu, M. Bruma, N. Belomoina, R.S. Begunov, Highly transparent and hydrophobic fluorinated polyimide films with orthokink structure, Eur. Polym. J. $50 \quad$ (2014) 200-213. doi:10.1016/j.eurpolymj.2013.10.030.

[13] H.R. Kricheldorf, Progress in Polyimide Chemistry I, Springer Berlin Heidelberg, Berlin, Heidelberg, 1999. doi:10.1007/3-540-49815-X.

[14] M. Ghosh, Polyimides: Fundamentals and Applications, CRC Press, 1996. 
[15] M. Barikani, Polyimides derived from diisocyanates, Iran. Polym. J. 11 (2002) 215236.

[16] G.W. Huber, S. Iborra, A. Corma, Synthesis of transportation fuels from biomass: Chemistry, catalysts, and engineering, Chem. Rev. 106 (2006) 4044-4098. doi:10.1021/cr068360d.

[17] Y. Zhu, C. Romain, C.K. Williams, Sustainable polymers from renewable resources, Nature. 540 (2016) 354-362. doi:10.1038/nature21001.

[18] P.F.H. Harmsen, M.M. Hackmann, H.L. Bos, Green building blocks for bio-based plastics, Biofuels, Bioprod. Biorefining. 8 (2014) 306-324. doi:10.1002/bbb.1468.

[19] R. Mülhaupt, Green polymer chemistry and bio-based plastics: Dreams and reality, Macromol. Chem. Phys. 214 (2013) 159-174. doi:10.1002/macp.201200439.

[20] A. Llevot, E. Grau, S. Carlotti, S. Grelier, H. Cramail, From lignin-derived aromatic compounds to novel biobased polymers, Macromol. Rapid Commun. 37 (2016) 9-28. doi:10.1002/marc.201500474.

[21] A. Gandini, T.M. Lacerda, A.J.F. Carvalho, E. Trovatti, Progress of polymers from renewable resources: Furans, vegetable oils, and polysaccharides, Chem. Rev. 116 (2016) 1637-1669. doi:10.1021/acs.chemrev.5b00264.

[22] D.K. Schneiderman, M.A. Hillmyer, 50 ${ }^{\text {th }}$ Anniversary perspective: There is a great future in sustainable polymers, Macromolecules. $50 \quad$ (2017) 3733-3749. doi:10.1021/acs.macromol.7b00293.

[23] H.T.H. Nguyen, P. Qi, M. Rostagno, A. Feteha, S.A. Miller, The quest for high glass transition temperature bioplastics, J. Mater. Chem. A. 6 (2018) 9298-9331. doi:10.1039/C8TA00377G.

[24] Z. Mi, Z. Liu, C. Wang, Y. Liu, C. Zhou, D. Wang, X. Zhao, H. Zhou, Y. Zhang, C. Chen, Transparent and soluble polyimide films containing 4,4'isopropylidenedicyclohexanol (Cis -HBPA) units: Preparation, characterization, thermal, mechanical, and dielectric properties, J. Polym. Sci. Part A Polym. Chem. (2018). doi:10.1002/pola.29172.

[25] Z. Mi, Z. Liu, C. Tian, X. Zhao, H. Zhou, D. Wang, C. Chen, Soluble polyimides 
containing 1,4:3,6-dianhydro-d-glucidol and fluorinated units: Preparation, characterization, optical, and dielectric properties, J. Polym. Sci. Part A Polym. Chem. 55 (2017) 3253-3265. doi:10.1002/pola.28700.

[26] G.N. Short, H.T.H. Nguyen, P.I. Scheurle, S.A. Miller, Aromatic polyesters from biosuccinic acid, Polym. Chem. 9 (2018) 4113-4119. doi:10.1039/C8PY00862K.

[27] A. Kumar, S. Tateyama, K. Yasaki, M.A. Ali, N. Takaya, R. Singh, T. Kaneko, Ultrahigh performance bio-based polyimides from 4,4'-diaminostilbene, Polymer. 83 (2016) 182-189. doi:10.1016/j.polymer.2015.12.008.

[28] J. Hu, Z. Wang, Z. Lu, C. Chen, M. Shi, J. Wang, E. Zhao, K. Zeng, G. Yang, Biobased adenine-containing high performance polyimide, Polymer. 119 (2017) 59-65. doi:10.1016/j.polymer.2017.05.012.

[29] R. Zhang, T. Li, H. Zhou, H. Huang, Y. Chen, Biobased transparent polyimides with excellent solubility and mechanical properties using myo-inositol derived diamines, React. Funct. Polym. 128 (2018) 91-96. doi:10.1016/j.reactfunctpolym.2018.05.006.

[30] R. Li, Z. Lu, Y. Liu, K. Zeng, J. Hu, G. Yang, The retarding effects and structural evolution of a bio-based high-performance polyimide during thermal imidization, J. Appl. Polym. Sci. 46953 (2018) e46953. doi:10.1002/app.46953.

[31] N.D. Ghatge, N.N. Maldar, Polyimides from dianhydride and diamine: structure property relations by thermogravimetric analysis (t.g.a.), Polymer. 25 (1984) 13531356. doi:10.1016/0032-3861(84)90390-2.

[32] R. Mathew, S. M. Vernekar, S. P. Mercier, R. Kerboua, Polyimides, process for the preparation thereof and use thereof as alignment films for liquid crystal devices, US20020142110, 2001. http://www.google.ch/patents/US6500913 (accessed August 5, 2017).

[33] L. B. Maktouf, I. Ghorbel, A. Afli, S. Abid, A. Gandini, Polyimides based on furanic diamines and aromatic dianhydrides: Synthesis, characterization and properties, Polym. Bull. 67 (2011) 1111-1122. doi:10.1007/s00289-010-0441-4.

[34] G. Yang, R. Zhang, H. Huang, L. Liu, L. Wang, Y. Chen, Synthesis of novel biobased polyimides derived from isomannide with good optical transparency, solubility and 
thermal stability, RSC Adv. 5 (2015) 67574-67582. doi:10.1039/C5RA14526K.

[35] A. Susa, J. Bijleveld, M. Hernandez, S.J. Garcia, Understanding the effect of the dianhydride structure on the properties of semiaromatic polyimides containing a biobased fatty diamine, ACS Sustain. Chem. Eng. 6 (2018) 668-678. doi:10.1021/acssuschemeng.7b03026.

[36] X. Ji, Z. Wang, J. Yan, Z. Wang, Partially bio-based polyimides from isohexidederived diamines, Polymer. 74 (2015) 38-45. doi:10.1016/j.polymer.2015.07.051.

[37] P. Suvannasara, S. Tateyama, A. Miyasato, K. Matsumura, T. Shimoda, T. Ito, Y. Yamagata, T. Fujita, N. Takaya, T. Kaneko, Biobased polyimides from 4aminocinnamic acid photodimer, Macromolecules. 47 (2014) 1586-1593. doi:10.1021/ma402499m.

[38] J.L. Cawse, J.L. Stanford, R.H. Still, Polymers from renewable sources, 1. Diamines and diisocyanates containing difurylalkane moieties, Die Makromol. Chemie. 185 (1984) 697-707. doi:10.1002/macp.1984.021850408.

[39] C.N.D. Neumann, W.D. Bulach, M. Rehahn, R. Klein, Water-free synthesis of polyurethane foams using highly reactive diisocyanates derived from 5hydroxymethylfurfural, Macromol. Rapid Commun. 32 (2011) 1373-1378. doi:10.1002/marc.201100205.

[40] A. Llevot, E. Grau, S. Carlotti, S. Grelier, H. Cramail, Renewable (semi)aromatic polyesters from symmetrical vanillin-based dimers, Polym. Chem. 6 (2015) 60586066. doi:10.1039/C5PY00824G.

[41] A. Llevot, E. Grau, S. Carlotti, S. Grelier, H. Cramail, Selective laccase-catalyzed dimerization of phenolic compounds derived from lignin: Towards original symmetrical bio-based (bis) aromatic monomers, J. Mol. Catal. B Enzym. 125 (2016) 34-41. doi:10.1016/j.molcatb.2015.12.006.

[42] S.-H. Hsiao, C.-P. Yang, S.-C. Huang, Preparation and properties of new polyimides and polyamides based on 1,4-bis(4-amino-2-trifluoromethylphenoxy)naphthalene, J. Polym. Sci. Part A Polym. Chem. 42 (2004) 2377-2394. doi:10.1002/pola.20075.

[43] C.W. Lee, S.M. Kwak, T.H. Yoon, Synthesis and characterization of polyimides from 
bis(3-aminophenyl)-2,3,5,6-tetrafluoro-4-trifluoromethylphenyl phosphine oxide (mDA7FPPO), Polymer. 47 (2006) 4140-4147. doi:10.1016/j.polymer.2006.03.002.

[44] I.A. Ronova, M. Bruma, Influence of chemical structure on glass transition temperature of polyimides, Struct. Chem. 21 (2010) 1013-1020. doi:10.1007/s11224010-9639-1. 